\title{
Overnutrition and the Cardiorenal Syndrome: Use of a Rodent Model to Examine Mechanisms
}

\author{
Adam Whaley-Connell ${ }^{a, c}$ Lakshmi Pulakat ${ }^{a-c, e}$ Vincent G. DeMarco ${ }^{a, b, d}$ \\ Melvin R. Hayden ${ }^{a}$ b Javad Habibi ${ }^{a}$ b Erik J. Henriksen ${ }^{g}$ James R. Sowers ${ }^{a}$, b, d, f

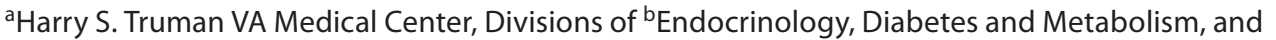 \\ cNephrology, Department of Internal Medicine, and Departments of ${ }^{\mathrm{d}}$ Medical Pharmacology and \\ Physiology, and eNutrition and Exercise Physiology, University of Missouri-Columbia School of Medicine, \\ and ${ }^{\mathrm{f} D i a b e t e s}$ and Cardiovascular Center, Columbia, Mo., and ${ }^{9}$ Department of Physiology, University of \\ Arizona College of Medicine, Tucson, Ariz., USA
}

\section{Key Words}

Cardiorenal syndrome $\cdot$ Heart/kidney disease $\cdot$ Obesity $\cdot$ Overnutrition $\cdot$ Zucker rat model

\begin{abstract}
Obesity has reached epidemic proportions with far-reaching health care and economic implications. Overnutrition, characterized by excess intake of carbohydrates and fats, has been associated with end-organ damage in several tissues, including the heart and the kidney. Furthermore, overnutrition is one of the most important modifiable and preventable causes of morbidity and mortality associated with cardiovascular and kidney diseases. Insulin resistance and compensatory hyperinsulinemia as well as associated mechanisms, including enhanced renin-angiotensinaldosterone system activity, inflammation, and oxidative stress, have been implicated in obesityrelated cardiorenal injury. In this review, the effect of overnutrition on heart and kidney disease is assessed in a rodent model of overnutrition and obesity, the Zucker obese rat.
\end{abstract}

Copyright $\odot 2011$ S. Karger AG, Basel

\section{Introduction}

Rates of overweight and obesity have increased strikingly over the past 3 decades, especially in minority and socioeconomically disadvantaged populations [1-11]. Overnutrition (especially when characterized by excessive intake of carbohydrates and fat) is a major contributor to increases in the incidence rates of hypertension, diabetes, and heart and kidney disease. These overweight-/obesity-related comorbidities appear to be driven, in part, by de- 


\section{CardioRenal Medicine}

\begin{tabular}{l|l}
\hline Cardiorenal Med 2011;1:23-30 \\
\hline $\begin{array}{l}\text { DOI: 10.1159/000322827 } \\
\text { Published online: January 17, } 2011\end{array}$ & $\begin{array}{l}\text { @ 2011 S. Karger AG, Basel } \\
\text { www.karger.com/crm }\end{array}$ \\
\hline
\end{tabular}

Whaley-Connell et al.: Rodent Model of Overnutrition and the Cardiorenal Syndrome
Fig. 1. Impact of overnutrition and Ang II on insulin metabolic signaling in the heart.

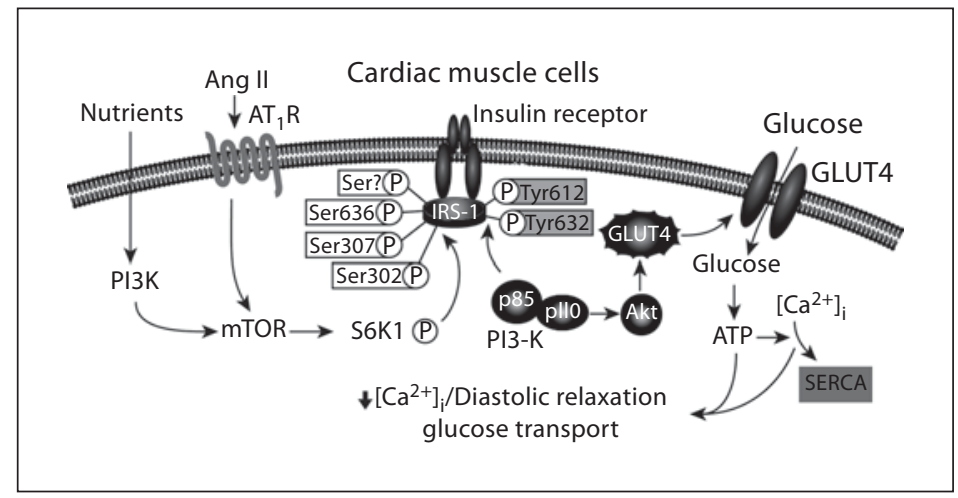

creases in insulin metabolic signaling in cardiac and renal tissue (fig. 1) [12-50]. In addition to insulin resistance, several other mechanisms, such as enhanced activation of the reninangiotensin-aldosterone system (RAAS), inflammation and oxidative stress, may help explain the linkage between overnutrition and heart and kidney disease. In this review, the effect of overnutrition on heart and kidney disease is assessed in a rodent model of overnutrition and obesity.

\section{A Rodent Model of Overnutrition and Heart Disease: The Zucker Obese Rat}

The Zucker obese (ZO) rat has been widely employed as a model of obesity-related heart and kidney injury and therefore represents a potentially important tool to investigate the cardiorenal syndrome [17]. Our laboratory and others have shown that the young ZO rat heart exhibits impaired insulin metabolic signaling (fig. 1) as well as abnormal cardiomyocyte and cardiac interstitial architecture (fig. 2a, b), and increased oxidative stress (fig. 2c, d) in conjunction with increased systemic insulin resistance (by homeostasis model assessment of insulin resistance) compared to the Zucker lean (ZL) rat [17]. The increased oxidative stress in the young ZO rat heart [17] is an important observation as the balance between the production and the elimination of reactive oxygen species (ROS) is critical in the preservation of normal cardiac function, especially for diastolic relaxation. Indeed, excessive myocardial ROS lead to abnormal myocardial structures and function $[12,17,25,38-41]$. These sources of excess ROS have been reported to result from increased nicotinamide adenine dinucleotide phosphate (NADPH) oxidase activity [17] and mitochondrial electron transport chain dysfunction [38, 39], as well as from mitochondrial antioxidant dysfunction [39]. These increases in oxidative stress and inflammation may help explain the increase in interstitial and perivascular fibrosis observed in young $\mathrm{ZO}$ rat hearts (fig. 2a, b). Impairments in diastolic relaxation depend, in part, on abnormalities in the passive properties of the ventricular wall that affect chamber compliance, such as excess accumulation of collagen and elastin fibers in the myocardium. Indeed, studies conducted in young $\mathrm{ZO}$ and ZL rats using highresolution cine magnetic resonance imaging showed that, compared to the $\mathrm{ZL}$ rat heart, the $\mathrm{ZO}$ rat heart exhibits left ventricular diastolic dysfunction due to a prolonged diastolic relaxation time and a reduced initial filling rate [17]. These abnormalities are associated with reductions in myocardial glucose uptake (fig. 3), insulin metabolic signaling and endothelial cell nitric oxide (NO) synthase activity, as well as increased activation of the mammalian target of the rapamycin (mTOR)/S6 kinase 1 (S6K-1) signaling pathway (fig. 1). Indeed, there is evolving evidence that overnutrition and enhanced RAAS activation may promote reduced tissue metabolic signaling through activation of this pathway [42-44]. 


\section{CardioRenal Medicine}

Fig. 2. The $\mathrm{ZO}$ rat heart manifests increased interstitial fibrosis $(\mathbf{a}, \mathbf{b})$ compared to the ZL rat heart due to increases in oxidative stress, i.e. 3-nitrotyrosine (c, d). The $\mathrm{ZO}$ rat heart (a) displays increased intensity of staining compared to the ZL rat heart (b) with Verhoeff-Van Gieson stain, which stains collagen pink. The $\mathrm{ZO}$ rat heart (c) displays increased intensity of immunostaining for 3-nitrotyrosine compared to the ZL rat heart (d).

\begin{tabular}{l|l}
\hline \multicolumn{2}{l}{ Cardiorenal Med 2011;1:23-30 } \\
\hline DOI: 10.1159/000322827 & $\begin{array}{l}\text { @ 2011 S. Karger AG, Basel } \\
\text { www.karger.com/crm }\end{array}$ \\
Published online: January 17, 2011 &
\end{tabular}

Whaley-Connell et al.: Rodent Model of Overnutrition and the Cardiorenal Syndrome

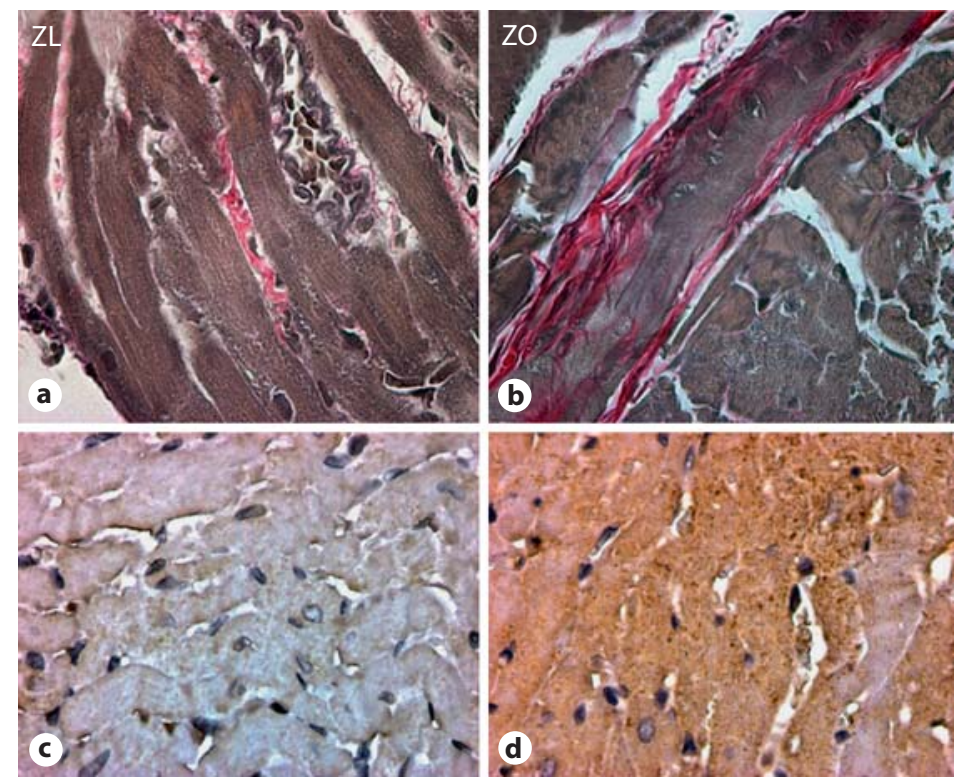

5 weeks
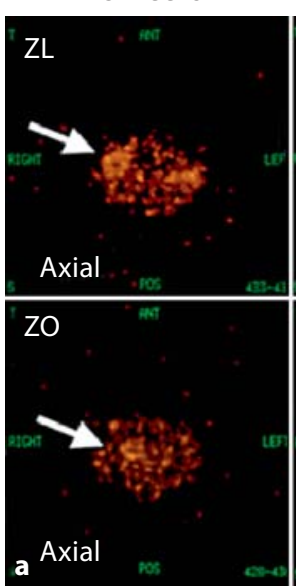

7 weeks
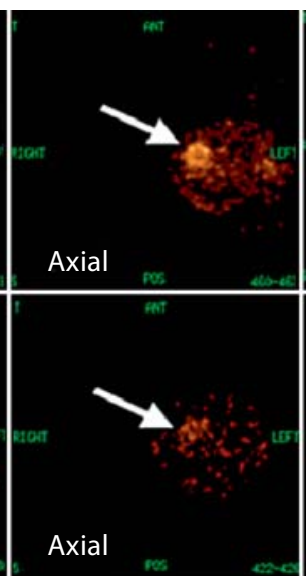

12 weeks

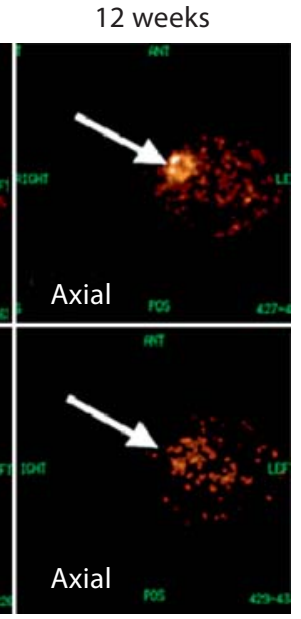

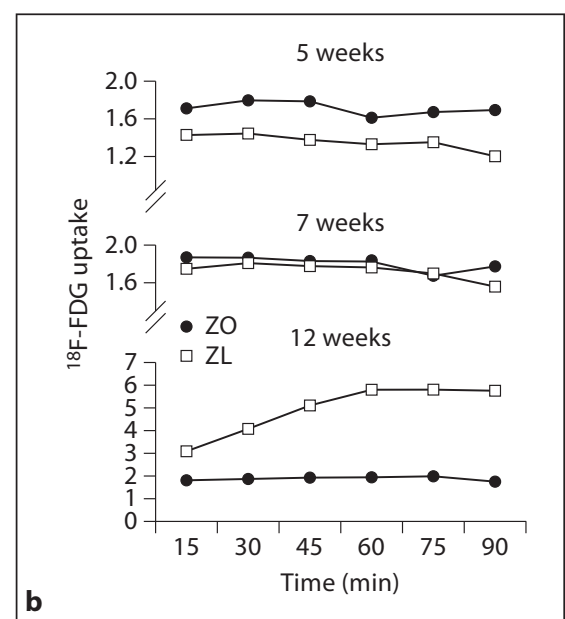

Fig. 3. Time course of micro-PET determination of insulin/glucose uptake in ZO rats. a Representative images of decreased ${ }^{18} \mathrm{~F}$-FDG uptake in the $\mathrm{ZO}$ (bottom panel) compared to the ZL rat (top panel) at 5, 7 and 12 weeks of age. b Time course of ${ }^{18} \mathrm{~F}$-FDG uptake over $90 \mathrm{~min}$. At 12 weeks, there is a trend to decreased uptake in $\mathrm{ZO}$ compared to $\mathrm{ZL}$ rats.

\section{A Model of Obesity-Related Kidney Disease}

Obesity and insulin resistance are increasingly recognized as independent risk factors for chronic kidney disease $[45,46]$. Mechanisms by which obesity and insulin resistance lead to kidney disease have been investigated in numerous models; however, the $\mathrm{ZO}$ rat is one of the best-characterized models for obesity-related kidney injury $[47,48]$. Observations from the $\mathrm{ZO}$ rat kidney suggest that activation of the renin-angiotensin system (RAS) in juxtaglomerular cells (fig. 4a) and proximal tubule cells (PTC) (fig. 4c) promotes a pro-inflammatory and pro-oxidative milieu (fig. 4b, d) and triggers obesity-induced mechanical forces which 
CardioRenal
Medicine
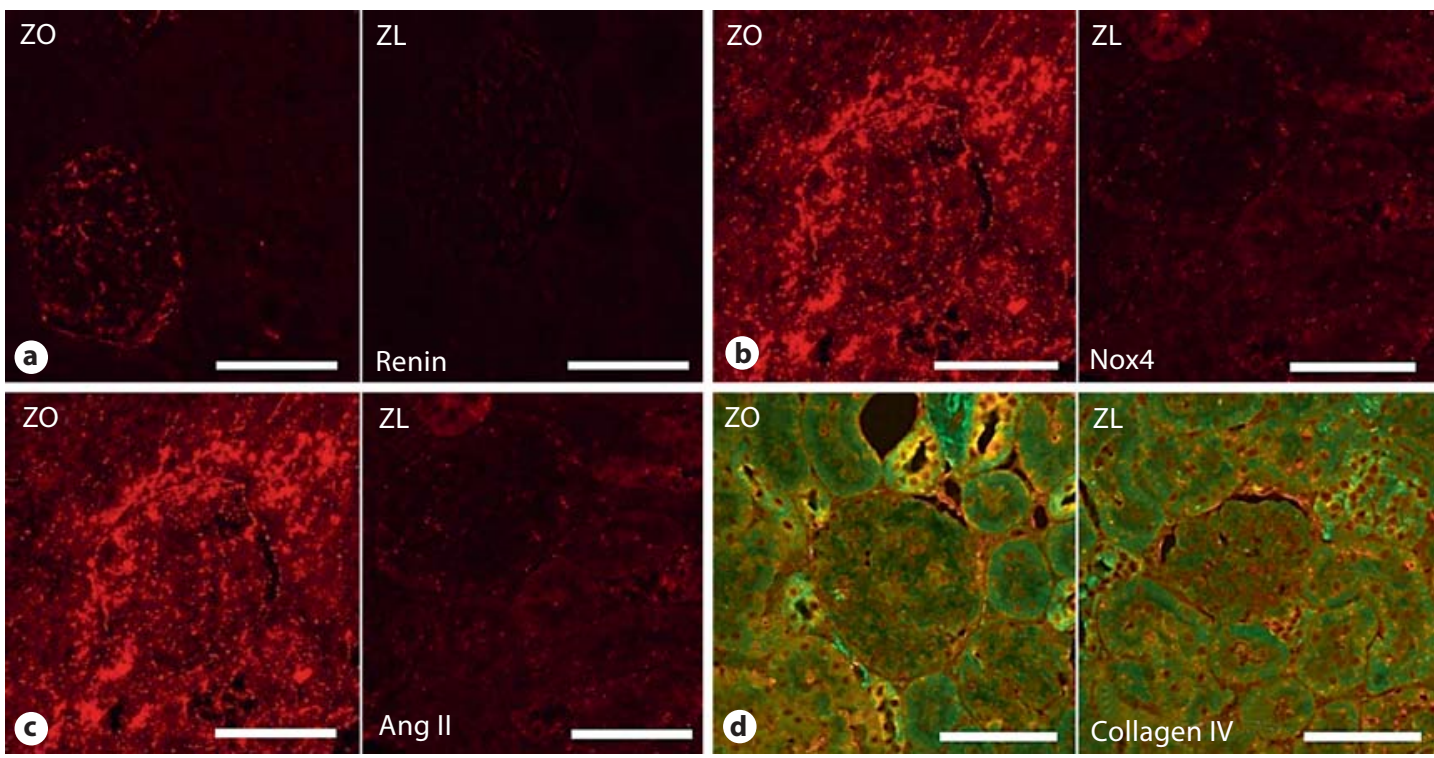

Fig. 4. ZO rat kidney manifests increased RAS activation with increases in juxtaglomerular renin (a) as well as tissue Ang II in the proximal tubule (c) compared to ZL controls. Tissue-based RAS increased vascular enzyme complex NADPH oxidase and subunits such as renal gp91-phox (Nox4) in the kidney (b). Activation of NADPH oxidase is critical in the generation of oxidative stress as it relates to structural remodeling and abnormal collagen deposition in the ZO rat kidney, as shown by staining with Verhoeff-Van Gieson stain, which stains collagen pink (d).

impair natriuresis and contribute to kidney injury [47-49]. These abnormalities, in turn, result in reductions in bioavailable $\mathrm{NO}$, thus enhancing renal injury and progressive kidney disease $[50,51]$. Importantly, increased renal NO appears to counter-regulate the effects of both the sympathetic nervous system and the RAAS in the renal regulation of salt and fluid homeostasis, as well as renal injury [52]. Treatment strategies which reduce oxidative stress and increase bioavailable NO are renoprotective in several rodent models of RAAS- and sympathetic nervous system-mediated renal injury, including the ZO rat model [49-54].

RAAS activation and decreased activity of natriuretic peptides are both involved in obesity and contribute to impaired natriuresis with increased sodium $\left(\mathrm{Na}^{+}\right)$reabsorption and resultant volume expansion [55]. Obesity has been implicated in altered intrarenal physical forces that play a role in abnormal pressure natriuresis and $\mathrm{Na}^{+}$retention. Observations from animal models of obesity and insulin resistance as well as studies in humans have demonstrated an increase in kidney weight attributable to endothelial cell proliferation and intrarenal lipid deposition, which can lead to altered intrarenal mechanical forces. This increased weight and the resultant elevated interstitial hydrostatic pressure lead to parenchymal collapse, followed by urinary outflow obstruction due to tubular collapse and increased sodium reabsorption due to reduced tubular flow. The increased $\mathrm{Na}^{+}$reabsorption produces a feedback-mediated renal vasodilatation, elevation of the glomerular filtration rate, and RAAS stimulation despite a state of relative volume expansion.

Evidence suggests that ROS are an important mediator of adverse RAAS-induced renal injury in models of obesity (fig. 4b, d) [52]. ROS are highly reactive molecules that oxidize lipids and proteins, cause cellular injury, and induce glomerular podocyte (fig. 5a) and renal epithelial PTC injury (fig. 5c, d) and associated proteinuria. ROS also promote uncoupling of endothelial NO synthase, thereby suppressing its activity, resulting in reductions in bioavailable NO, and cause impairments in vasodilation. Increased tissue levels of ROS can 


\section{CardioRenal \\ Medicine}

\begin{tabular}{l|l}
\hline \multicolumn{2}{l}{ Cardiorenal Med 2011;1:23-30 } \\
\hline DOI: 10.1159/000322827 & $\begin{array}{l}\text { @ 2011 S. Karger AG, Basel } \\
\text { www.karger.com/crm }\end{array}$ \\
\hline
\end{tabular}

Whaley-Connell et al.: Rodent Model of Overnutrition and the Cardiorenal Syndrome

ZO

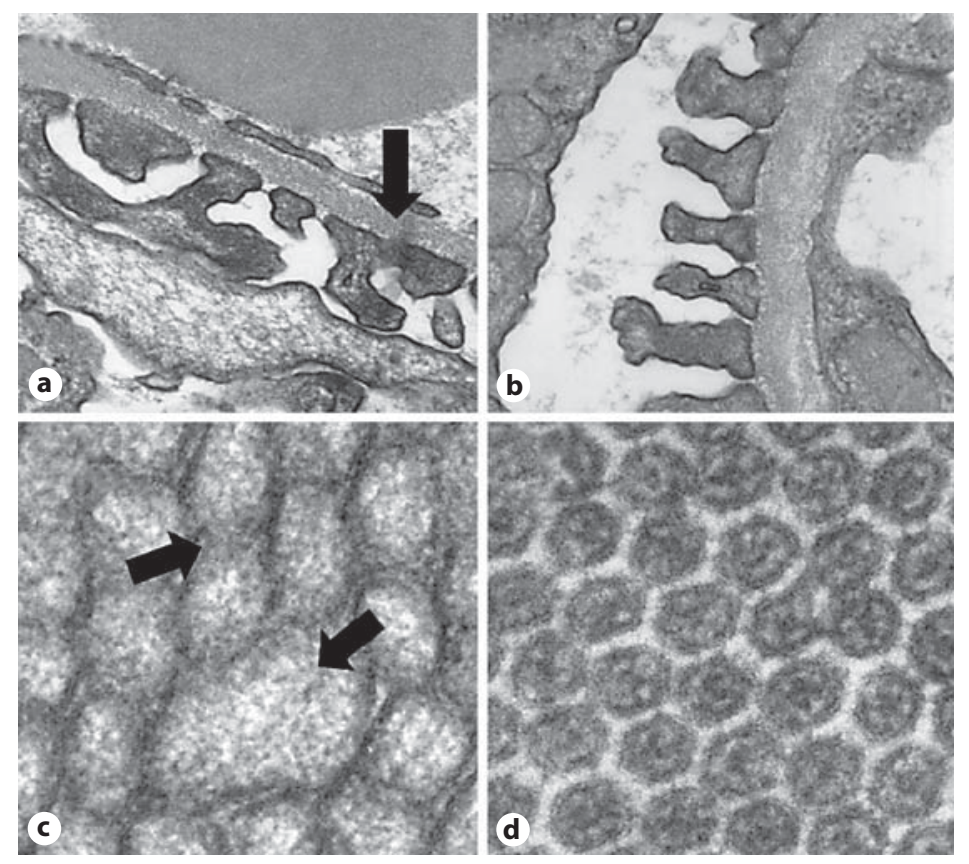

Fig. 5. Podocyte foot process and $\mathrm{PTC}$ remodeling in the $\mathrm{ZO}$ compared to the ZL rat. a Images of ultrastructural analysis of the glomerular filtration barrier utilizing transmission electron microscopy. The ZO rat (a) displays podocyte foot process effacement and fusion (arrow) with loss of the slit-pore diaphragm compared to the ZL rat (b), findings consistent with the development of proteinuria. The development of proteinuria is coupled with parallel findings of structural remodeling of proximal tubule microvilli in $\mathrm{ZO}$ (c) compared to ZL rats (d). The $\mathrm{ZO}$ rat demonstrates enlarged microvilli with multiple abnormal forms (arrows) which are not found in ZL rats.

.

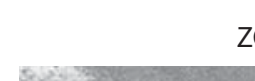




\section{CardioRenal \\ Medicine}

\begin{tabular}{l|l}
\hline Cardiorenal Med 2011;1:23-30 \\
\hline DOI: 10.1159/000322827 & $\begin{array}{l}\text { @ } 2011 \text { S. Karger AG, Basel } \\
\text { www.karger.com/crm }\end{array}$ \\
\hline Published online: January 17, 2011 &
\end{tabular}

Whaley-Connell et al.: Rodent Model of Overnutrition and the Cardiorenal Syndrome

of metabolic/diabetic kidney disease, we need to consider contributions from impairments in either the retrieval or degradation process in the proximal tubule as well (fig. 5b) [57, 58].

In keeping with PTC injury contributing to proteinuria in the young insulin-resistant ZO rat model, urinary levels of $\gamma$-glutamyl transferase, a specific urinary marker for injury to the PTC brush border, are increased [57]. Our findings of increased urinary levels of $\gamma$-glutamyl transferase suggest a potential mechanism of impaired retrieval/degradation in this obese insulin-resistant rodent model. This notion is supported by modest reductions in the PTCspecific proteins megalin and lysosomal-associated membrane protein (LAMP-2) in the ZO rat. These PTC proteins are responsible for the endocytotic/lysosomal mechanism and further substantiate impairments in protein reabsorption/degradation concomitant with PTC injury [59]. Our ultrastructural observations additionally support maladaptive PTC remodeling with loss of basal polarity due to mitochondrial remodeling, loss of invaginating canalicular plasma membrane infoldings, and PTC thickening. Collectively, these data suggest that there is a proximal tubular origin of proteinuria with impaired tubular endocytosis of protein and a functionally impaired retrieval mechanism in models of obesity-induced renal injury.

Megalin is a critical protein which is directly and indirectly involved in the retrieval mechanism of albumin reabsorption: directly as a receptor and indirectly by its effects on the expression of cubilin, which is co-expressed with megalin in the brush border and the endocytic apparatus. Recent data highlight the impact of obesity on RAS activation and disruption of the retrieval mechanism in PTC $[57,59]$ and, specifically, the impact angiotensin II (Ang II) has on the disruption of cytoskeletal organization. This endocytic pathway is especially susceptible to metabolic factors and growth factors such as Ang II and aldosterone. Data from PTC culture models as well as small animal models of obesity, such as the ZO rat model, support the concept that increased $A T_{1}$ receptor $\left(A T_{1} R\right)$ pathway signaling reduces megalin expression and that blockade of $\mathrm{AT}_{1} \mathrm{R}$ improves megalin expression and lysosomal degradation of albumin. Consistent with our ultrastructural observations in the $\mathrm{ZO}$ rat and other insulin-resistant models, reduced megalin expression has been associated with loss of PTC endocytic invaginations/vesicles, reduced lysosomes and loss of canilicular integrity [56-58]. Our findings of markers of increased renal RAAS activation in the proximal tubule region suggest the possibility that RAAS-dependent reductions in megalin expression are closely associated with the impairment in the retrieval mechanism. However, the precise mechanisms in obesity-induced renal injury have yet to be elucidated.

To conclude, the data obtained from rodent models of obesity and insulin resistance, such as the ZO rat model, support the notion that obesity contributes to the activation of circulating RAAS but also tissue RAS components and to reduced insulin metabolic signaling that lead to NADPH oxidase generation of ROS and subsequent heart and kidney injury.

\section{References}

1 Flegal KM, Carroll MD, Ogden CL, Curtin LR: Prevalence and trends in obesity among US adults, 1999-2008. JAMA 2010;303:235-241.

2 Sturm R: Increases in morbid obesity in the USA: 2000-2005. Public Health 2007;121:492-496.

- 3 Bell AC, Adair LS, Popkin BM: Ethnic differences in the association between body mass index and hypertension. Am J Epidemiol 2002;155:346-353.

4 Sowers JR: Obesity as a cardiovascular risk factor. Am J Med 2003;115(suppl 8A):37S-41S.

5 Alley DE, Chang VW: The changing relationship of obesity and disability, 1988-2004. JAMA 2007;298:2020-2027. Minkler M, Fuller-Thomson E, Guralnik JM: Gradient of disability across the socioeconomic spectrum in the United States. N Engl J Med 2006;355:695-703.

7 Goodpaster BH, DeLany JP, Otto AD, Kuller L, Vockley J, South-Paul JE, Thomas SB, Brown J, McTigue K, Hames KC, Lang W, Jakicic JM: Effects of diet and physical activity interventions on weight loss and cardiometabolic risk factors in severely obese adults. JAMA 2010;304:1795-1802. 


\section{CardioRenal Medicine}

\begin{tabular}{l|l}
\hline Cardiorenal Med 2011;1:23-30 \\
\hline $\begin{array}{l}\text { DOI: 10.1159/000322827 } \\
\text { Published online: January 17, } 2011\end{array}$ & $\begin{array}{l}\text { @ 2011 S. Karger AG, Basel } \\
\text { www.karger.com/crm }\end{array}$ \\
\hline
\end{tabular}

Whaley-Connell et al.: Rodent Model of Overnutrition and the Cardiorenal Syndrome

-8 Alberti KG, Eckel RH, Grundy SM, Zimmet PZ, Cleeman JI, Donato KA, Fruchart JC, James WP, Loria CM, Smith SC Jr, International Diabetes Federation Task Force on Epidemiology and Prevention, National Heart, Lung, and Blood Institute, American Heart Association, World Heart Federation, International Atherosclerosis Society, International Association for the Study of Obesity: Harmonizing the metabolic syndrome: a joint interim statement of the International Diabetes Federation Task Force on Epidemiology and Prevention; National Heart, Lung, and Blood Institute; American Heart Association; World Heart Federation; International Atherosclerosis Society; and International Association for the Study of Obesity. Circulation 2009;120:1640-1645.

-9 McGee DL: Body mass index and mortality: a meta-analysis based on person-level data from twenty-six observational studies. Ann Epidemiol 2005;15:87-97.

10 Ghandehari H, Le V, Kamal-Bahl S, Bassin SL, Wong ND: Abdominal obesity and the spectrum of global cardiometabolic risks in US adults. Int J Obes (Lond) 2009;33:239-248.

11 Centers for Disease Control and Prevention (CDC): Differences in prevalence of obesity among black, white, and Hispanic adults - United States, 2006-2008. MMWR Morb Mortal Wkly Rep 2009;58:740-744.

12 Govindarajan G, Hayden MR, Cooper SA, Figueroa SD, Ma L, Hoffman TJ, Stump CS, Sowers JR: Metabolic derangements in the insulin-resistant heart. J Cardiometab Syndr 2006;1:102-106.

13 Schenk S, Saberi M, Olefsky JM: Insulin sensitivity: modulation by nutrients and inflammation. J Clin Invest 2008; 118:2992-3002.

14 Kim JA, Wei Y, Sowers JR: Role of mitochondrial dysfunction in insulin resistance. Circ Res 2008;102:401-414.

15 Morris EM, Whaley-Connell AT, Thyfault JP, Britton SL, Koch LG, Wei Y, Ibdah JA, Sowers JR: Low aerobic capacity and high-fat diet contribute to oxidative stress and IRS-1 degradation in the kidney. Am J Nephrol 2009;30:112-119. Whaley-Connell A, Sowers JR: Hypertension and insulin resistance. Hypertension 2009;54:462-464.

$>16$
$>17$ Zhou X, Ma L, Habibi J, Whaley-Connell A, Hayden MR, Tilmon RD, Brown AN, Kim JA, DeMarco VG, Sowers JR: Nebivolol improves diastolic dysfunction and myocardial remodeling through reductions in oxidative stress in the Zucker obese rat. Hypertension 2010;55:880-888.

18 Ferreira AJ, Santos RA, Bradford CN, Mecca AP, Sumners C, Katovich MJ, Raizada MK: Therapeutic implications of the vasoprotective axis of the renin-angiotensin system in cardiovascular diseases. Hypertension 2010;55:207-213.

19 Motley ED, Eguchi K, Gardner C, Hicks AL, Reynolds CM, Frank GD, Mifune M, Ohba M, Eguchi S: Insulin-induced Akt activation is inhibited by angiotensin II in the vasculature through protein kinase C-alpha. Hypertension 2003; 41(3 Pt 2):775-780.

20 Carvalheira JB, Calegari VC, Zecchin HG, Nadruz W Jr, Guimarães RB, Ribeiro EB, Franchini KG, Velloso LA, Saad MJ: The cross-talk between angiotensin and insulin differentially affects phosphatidylinositol 3-kinase- and mitogenactivated protein kinase-mediated signaling in rat heart: implications for insulin resistance. Endocrinology 2003;144: 5604-5614.

21 Andreozzi F, Laratta E, Sciacqua A, Perticone F, Sesti G: Angiotensin II impairs the insulin signaling pathway promoting production of nitric oxide by inducing phosphorylation of insulin receptor substrate-1 on Ser312 and Ser616 in human umbilical vein endothelial cells. Circ Res 2004;94:1211-1218. Wei Y, Whaley-Connell AT, Chen K, Habibi J, Uptegrove GM, Clark SE, Stump CS, Ferrario CM, Sowers JR: NADPH oxidase contributes to vascular inflammation, insulin resistance, and remodeling in the transgenic (mRen2) rat. Hypertension 2007;50:384-391. Ren J, Samson WK, Sowers JR: Insulin-like growth factor 1 as a cardiac hormone: physiological and pathophysiological implications in heart disease. J Mol Cell Cardiol 1999;31:2049-2061.

24 Ren J, Sowers JR, Walsh MF: Reduced contractile response to insulin and IGF-I in ventricular myocytes from genetically obese Zucker rats. Am J Physiol Heart Circ Physiol 2000;279:H1708-H1714.

25 Privratsky JR, Wold LE, Sowers JR, Ren J: AT1 blockade prevents glucose-induced cardiac dysfunction in ventricular myocytes: role of the AT1 receptor and NADPH oxidase. Hypertension 2003;42:206-212.

26 Gropler RJ: Methodology governing the assessment of myocardial glucose metabolism by positron emission tomography and fluorine 18-labeled fluorodeoxyglucose. J Nucl Cardiol 1994;1(2 Pt 2):S4-S14.

27 Dutka DP, Pitt M, Pagano D: Myocardial glucose transport and utilization in patients with type 2 diabetes mellitus, left ventricular dysfunction, and coronary artery disease. J Am Coll Cardiol 2006;48:2225-2231.

28 Ouwens DM, Boer C, Fodor M, de Galan P, Heine RJ, Maassen JA: Cardiac dysfunction induced by high-fat diet is associated with altered myocardial insulin signalling in rats. Diabetologia 2005;48:1229-1237.

-29 Scognamiglio R, Negut C, De Kreutzenberg SV, Tiengo A, Avogaro A: Postprandial myocardial perfusion in healthy subjects and in type 2 diabetic patients. Circulation 2005;112:179-184.

30 Aasum E, Hafstad AD, Severson DL, Larsen TS: Age-dependent changes in metabolism, contractile function, and ischemic sensitivity in hearts from db/db mice. Diabetes 2003;52:434-441.

Sundell J, Knuuti J: Insulin and myocardial blood flow. Cardiovasc Res 2003;57:312-319.

32 Peterson LR, Herrero P, Schechtman KB: Effect of obesity and insulin resistance on myocardial substrate metabolism and efficiency in young women. Circulation 2004;109:2191-2196.

-33 Warnock DG, Muntner P, McCullough PA, Zhang X, McClure LA, Zakai N, Cushman M, Newsome BB, Kewalramani R, Steffes MW, Howard G, McClellan WM: Kidney function, albuminuria, and all-cause mortality in the REGARDS (Reasons for Geographic and Racial Differences in Stroke) study. Am J Kidney Dis 2010;56:861-871.

-34 Toto RD, Greene T, Hebert LA, Hiremath L, Lea JP, Lewis JB, Pogue V, Sika M, Wang X, AASK Collaborative Research Group: Relationship between body mass index and proteinuria in hypertensive nephrosclerosis: results from the African American Study of Kidney Disease and Hypertension (AASK) cohort. Am J Kidney Dis 2010;56:896906. 


\section{CardioRenal Medicine}

\begin{tabular}{l|l}
\hline Cardiorenal Med 2011;1:23-30 \\
\hline $\begin{array}{l}\text { DOI: 10.1159/000322827 } \\
\text { Published online: January 17, } 2011\end{array}$ & $\begin{array}{l}\text { @ 2011 S. Karger AG, Basel } \\
\text { www.karger.com/crm }\end{array}$ \\
\hline
\end{tabular}

Whaley-Connell et al.: Rodent Model of Overnutrition and the Cardiorenal Syndrome
$>35$

36

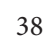

\section{dosteronism patients. J Hypertens 2010;28:2120-2126}

Serpillon S, Floyd BC, Gupte RS, George S, Kozicky M, Neito V, Recchia F, Stanley W, Wolin MS, Gupte SA: Superoxide production by $\mathrm{NAD}(\mathrm{P}) \mathrm{H}$ oxidase and mitochondria is increased in genetically obese and hyperglycemic rat heart and aorta before the development of cardiac dysfunction. The role of glucose-6-phosphate dehydrogenase-derived NADPH. Am J Physiol Heart Circ Physiol 2009;297:H153-H162.

Ren J, Pulakat L, Whaley-Connell A, Sowers JR: Mitochondrial biogenesis in the metabolic syndrome and cardiovascular disease. J Mol Med 2010;88:993-1001.

-40 Young ME, Guthrie PH, Razeghi P, Leighton B, Abbasi S, Patil S, Youker KA, Taegtmeyer H: Impaired long-chain fatty acid oxidation and contractile dysfunction in the obese Zucker rat heart. Diabetes 2002;51:2587-2595.

Coort SL, Hasselbaink DM, Koonen DP, Willems J, Coumans WA, Chabowski A, van der Vusse GJ, Bonen A, Glatz JF, Luiken JJ: Enhanced sarcolemmal FAT/CD36 content and triacylglycerol storage in cardiac myocytes from obese Zucker rats. Diabetes 2004;53:1655-1663. Metab 2006;3:393-402.

Tremblay F, Brûlé S, Um SH, Li Y, Masuda K, Roden M, Sun XJ, Brebs M, Polakiewicz RD, Thomas G, Marette A Identification of IRS-1 Ser-1101 as a target of S6K1 in nutrient- and obesity-induced insulin resistance. Proc Natl Acad Sci USA 2007;104:14056-14061.

-44 Mayer CM, Belsham DD: Central insulin signaling is attenuated by long-term insulin exposure via insulin receptor substrate-1 serine phosphorylation, proteasomal degradation, and lysosomal insulin receptor degradation. Endocrinology 2010;151:75-84.

45 Hsu CY, McCulloch CE, Iribarren C, Darbinian J, Go AS: Body mass index and risk for end-stage renal disease. Ann Intern Med 2006;144:21-28.

46 Soc Nephrol 2006;17:1695-1702.

$>47$ Aleixandre de Artiñano A, Miguel Castro M: Experimental rat models to study the metabolic syndrome. Br J Nutr 2009;102:1246-1253.

$>_{48}$ Baynes J, Murrray DB: Cardiac and renal function are progressively impaired with aging in Zucker diabetic fatty type II diabetic rats. Oxid Med Cell Longev 2009;2:328-334.

-49 Coimbra TM, Janssen U, Gröne HJ, Ostendorf T, Kunter U, Schmidt H, Brabant G, Floege J: Early events leading to renal injury in obese Zucker (fatty) rats with type II diabetes. Kidney Int 2000;57:167-182.

50 Trujillo J, Ramírez V, Pérez J, Torre-Villalvazo I, Torres N, Tovar AR, Muñoz RM, Uribe N, Gamba G, Bobadilla NA: Renal protection by a soy diet in obese Zucker rats is associated with restoration of nitric oxide generation. Am J Physiol Renal Physiol 2005;288:F108-F116.

-51 Erdely A, Freshour G, Maddox DA, Olson JL, Samsell L, Baylis C: Renal disease in rats with type 2 diabetes is associated with decreased renal nitric oxide production. Diabetologia 2004;47:1672-1676.

52 Nistala R, Whaley-Connell A, Sowers JR: Redox control of renal function and hypertension. Antioxid Redox Signal 2008;10:2047-2089.

$>53$ Blanco S, Bonet J, López D, Casas I, Romero R: ACE inhibitors improve nephrin expression in Zucker rats with glomerulosclerosis. Kidney Int Suppl 2005;93:S10-S14.

54 Hayden MR, Habibi J, Whaley-Connell A, Sowers D, Johnson M, Tilmon R, Jain D, Ferrario CM, Sowers JR: Nebivolol attenuates maladaptive proximal tubule remodeling in transgenic rats. Am J Nephrol 2010;31:262-272.

55 Hall JE, Crook ED, Jones DW, Wofford MR, Dubbert PM: Mechanisms of obesity-associated cardiovascular and renal disease. Am J Med Sci 2002;324:127-137.

56 Whaley-Connell A, Rehmer N, Habibi J, Rehmer J, Ferrario CM, Sowers JR: Nebivolol reduces proteinuria and renal NADPH oxidase-generated reactive oxygen species in the transgenic Ren2 rat. Am J Nephrol 2009;30:354-360.

57 Habibi J, Hayden MR, Sowers JR, Pulakat L, Elliott D, Tilmon RD, Manrique C, Lastra G, DeMarco VG, Whaley Connell A: Nebivolol attenuates redox-sensitive glomerular and tubular mediated proteinuria in obese rats. Endocrinology 2010, in press.

58 Whaley-Connell A, Lastra G, Manrique C, Nistala R, Cooper SA, Westerly B, Wiedmeyer C, Miner J, Chowdhury N, Stump CS, Sowers JR: Insulin resistance, oxidative stress, and podocyte injury: role of rosuvastatin modulation of filtration barrier injury. Am J Nephrol 2008;28:67-75.

59 Russo LM, Sandoval RM, Campos SB, Molitoris BA, Comper WD, Brown D: Impaired tubular uptake explains albuminuria in early diabetic nephropathy. J Am Soc Nephrol 2009;20:489-494.

60 Alonso-Galicia M, Brands MW, Zappe DH, Hall JE: Hypertension in obese Zucker rats. Role of angiotensin II and adrenergic activity. Hypertension 1996;28;1047-1054.

61 Kuwabara A, Satoh M, Tomita N, Sasaki T, Kashihara N: Deterioration of glomerular endothelial surface layer induced by oxidative stress is implicated in altered permeability of macromolecules in Zucker fatty rats. Diabetologia 2010;53: 2056-2065. 